\title{
Halobacillus profundi sp. nov. and Halobacillus kuroshimensis sp. nov., moderately halophilic bacteria isolated from a deep-sea methane cold seep
}

\author{
Ngoc-Phuc Hua, ${ }^{1}$ Atsuko Kanekiyo, ${ }^{1}$ Katsunori Fujikura, ${ }^{1,2}$ Hisato Yasuda ${ }^{3}$ \\ and Takeshi Naganuma ${ }^{1}$
}

Correspondence

Takeshi Naganuma takn@hiroshima-u.ac.jp

\author{
${ }^{1}$ Graduate School of Biosphere Science, Hiroshima University, Kagamiyama, Higashi-Hiroshima \\ 739-8528, Japan \\ 2Japan Agency for Marine-Earth Science and Technology, Natsushima-cho, Yokosuka \\ 237-0061, Japan \\ ${ }^{3}$ Center for Advanced Marine Core Research, Kochi University, Monobe, Nankoku 783-8502, \\ Japan
}

Two Gram-positive, rod-shaped, moderately halophilic bacteria were isolated from a deep-sea carbonate rock at a methane cold seep in Kuroshima Knoll, Japan. These bacteria, strains IS-Hb4 ${ }^{\top}$ and IS-Hb7 ${ }^{\top}$, were spore-forming and non-motile. They were able to grow at temperatures as low as $9^{\circ} \mathrm{C}$ and hydrostatic pressures up to $30 \mathrm{MPa}$. Based on high sequence similarity of their 16S rRNA genes to those of type strains of the genus Halobacillus, from $96.4 \%$ (strain IS-Hb7 ${ }^{\top}$ to Halobacillus halophilus NCIMB $9251^{\top}$ ) to $99.4 \%$ (strain IS-Hb4 ${ }^{\top}$ to Halobacillus dabanensis $\left.D-8^{\top}\right)$, the strains were shown to belong to this genus. DNA-DNA relatedness values of $49.5 \%$ and 1.0-33.0\%, respectively, were determined between strains IS- $\mathrm{Hb} 4^{\top}$ and IS- $\mathrm{Hb} 7^{\top}$ and between these strains and other Halobacillus type strains. Both strains showed the major menaquinone MK7 and L-Orn-D-Asp cell-wall peptidoglycan type. Straight-chain $\mathrm{C}_{16: 0}$, unsaturated $\mathrm{C}_{16: 1} \omega 7 \mathrm{c}$ alcohol and $\mathrm{C}_{18: 1} \omega 7 \mathrm{c}$ and cyclopropane $\mathrm{C}_{19: 0}$ cyc fatty acids were predominant in both strains. The DNA G + C contents of IS- $\mathrm{Hb} 4^{\top}$ and IS- $\mathrm{Hb} 7^{\top}$ were respectively 43.3 and $42.1 \mathrm{~mol} \%$.

Physiological and biochemical analyses combined with DNA-DNA hybridization results allowed us to place strains IS-Hb4 ${ }^{\top}\left(=\mathrm{JCM} 14154^{\top}=\mathrm{DSM} 18394^{\top}\right)$ and IS-Hb7 ${ }^{\top}\left(=\mathrm{JCM} 14155^{\top}=\mathrm{DSM}\right.$ $18393^{\top}$ ) in the genus Halobacillus as the respective type strains of the novel species Halobacillus profundi sp. nov. and Halobacillus kuroshimensis sp. nov.
The genus Halobacillus, with the type species Halobacillus halophilus, was established and described by Spring and co-workers in 1996 (Claus et al., 1983; Spring et al., 1996). So far, nine species of this genus have been identified (Amoozegar et al., 2003a, b; Yoon et al., 2003, 2004, 2005; Liu et al., 2005). The increasing number of publications on bio-applications and other aspects of Halobacillus and the large number of $16 \mathrm{~S}$ rRNA gene sequences deposited in databases for unidentified species reflect the wide distribution of these bacteria and their considerable scientific

\section{Abbreviation: CZE, capillary zone electrophoresis.}

The GenBank/EMBL/DDBJ accession numbers for the 16S rRNA

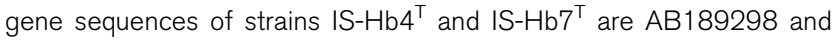
AB195680.

Genetic relatedness of strains $1 \mathrm{~S}-\mathrm{Hb} 4^{\top}$ and $1 \mathrm{~S}-\mathrm{Hb} 7^{\top}$ to related Halobacillus type strains and differential carbon source utilization patterns are available with the online version of this paper. interest (Burja et al., 1999; Pinar et al., 2001; Yang et al., 2002; Rivadeneyra et al., 2004). In our investigations of the diversity of halophilic bacteria in various habitats over the last few years, we obtained strains IS- $\mathrm{Hb} 4^{\mathrm{T}}$ and IS- $\mathrm{Hb} 7^{\mathrm{T}}$ in an endemic population from a carbonate rock collected at a deep-sea methane seep at Kuroshima Knoll, south-western Japan. Living in the special environment of low temperature, high pressure and low oxygen availability, these bacteria possess several features that are different from those of described species that would be considered evidence of interesting adaptation.

Samples from which the bacteria were isolated, carbonate rocks authentically formed in a methane seep of the Kuroshima Knoll, located at $642 \mathrm{~m}$ depth at $24^{\circ} 07.8^{\prime} \mathrm{N}$ $124^{\circ} 11.2^{\prime}$ E (Fujikura et al., 2003; Inagaki et al., 2004), were collected with the remotely operated vehicle Dolphin $3 K$, operated by the Japan Agency for Marine Earth Science and 
Technology (JAMSTEC). The in situ water temperature, salinity (electric conductivity) and methane concentration were $7.6{ }^{\circ} \mathrm{C}, 35.5 \mathrm{mS} \mathrm{cm}^{-1}$ and $\sim 1 \mu \mathrm{M}$. An enrichment medium containing $0.5 \%(\mathrm{w} / \mathrm{v})$ Bacto-peptone (Difco), $0.25 \%$ yeast extract (Difco), $0.1 \%$ D-glucose (Wako) and $15 \% \mathrm{NaCl}$ (Okamoto et al., 2001; Okamoto \& Naganuma, 2003; Okamoto, 2004) in distilled water was used to culture and store the new isolates at $30^{\circ} \mathrm{C}$, except for certain changes in salinity and temperature in some tests. Distinct single colonies on $1.5 \%$ agar plates of the generic medium were selected and isolated at least three times to obtain pure cultures. Type strains Halobacillus halophilus DSM $2266^{\mathrm{T}}$, Halobacillus litoralis DSM $10405^{\mathrm{T}}$, Halobacillus salinus JCM $11546^{\mathrm{T}}$, Halobacillus trueperi DSM $10404^{\mathrm{T}}$, Halobacillus karajensis DSM $14948^{\mathrm{T}}$, Halobacillus locisalis DSM $16468^{\mathrm{T}}$, Halobacillus yeomjeoni DSM $17110^{\mathrm{T}}$, Halobacillus aidingensis DSM $18198^{\mathrm{T}}$ and Halobacillus dabanensis DSM $18199^{\mathrm{T}}$ were used as reference strains.

Gram reaction, acid-fast staining, motility and endospore observation, enzyme activities (catalase, urease, phenylalanine deaminase, oxidase) and hydrolysis of starch, aesculin, gelatin and casein were tested according to conventional protocols (Doetsch, 1981; Smibert \& Krieg, 1981). For anaerobic growth and nitrate reduction examination, the bacteria were tested using the same medium in which they grew well in isolation step both on agar plates and in liquid broth in an anaerobic atmosphere of (v/v) $80 \% \mathrm{~N}_{2}, 10 \%$ $\mathrm{CO}_{2}$ and $10 \% \mathrm{H}_{2}$ (Te-Her Anaero-Box ANX-1 system; Hirasawa). Media (in flasks for agar culture and in test tubes for liquid culture) were well gassed under nitrogen to remove oxygen before being autoclaved. Test tubes and agar plates were manipulated inside the anaerobic chamber. Any residual oxygen carried over or generated unexpectedly by the culture procedure inside the chamber was detected by an oxygen sensor and eliminated by the system until undetectable. Colonies and $\mathrm{OD}_{600}$ were observed to determine anaerobic growth. Liquid medium supplemented with $0.1 \% \mathrm{KNO}_{3}$ in test tubes containing Durham tubes was inoculated aerobically and anaerobically for nitrate reduction assay. Escherichia coli K-12 and Virgibacillus marismortui DSM $12325^{\mathrm{T}}$ were used as positive controls and $H$. litoralis DSM $10405^{\mathrm{T}}$, H. trueperi DSM $10404^{\mathrm{T}}$ and $H$. salinus JCM $11546^{\mathrm{T}}$ were used as negative controls; uninoculated medium was also included. Sulfanilic acid and $\alpha$-naphthylamine solutions and zinc powder were used to detect formation of nitrite and denitrification as described in the conventional method (Smibert \& Krieg, 1981). Ability to utilize single carbon sources was tested using Biolog microplates based on the instructions of the manufacturer and previous studies (Garland \& Mills, 1991; Garland, 1996, 1999). Acid production from carbohydrates was assayed using API 50CH and API 20 CE kits (bioMérieux). Aerobic growth at hydrostatic pressures of $0.1,10,20$ and $30 \mathrm{MPa}$ was examined using stainless-steel pressure vessels (Rigosha) compressed with a high-pressure stainless steel hand pump model 11-100 equipped with a pressure gauge (Enerpac). Inoculated liquid medium with $10 \% \mathrm{NaCl}$ added was filled into sterile polyethylene transfer pipettes. The pipettes were then heat-sealed with complete exclusion of air bubbles and incubated in the pressure vessels under a certain pressure at room temperature for 1 week. Bacterial growth was observed as turbidity or formation of cell clumps.

Bacterial cells from cultures at stationary phase were harvested and genomic DNA was extracted according to protocol described by Wilson (1995). The PCR procedure of DeLong (1992) for amplifying the 16S rRNA gene was followed. Nearly full-length sequences ( $\sim 1500 \mathrm{bp})$ of amplified 16S rRNA genes were obtained using a Dual CyDye Terminator sequencing kit (Amersham Biosciences) and sequenced with a Long-Read Tower sequencer (Visible Genetics). The sequences obtained were used to search for similarity on public databases (DDBJ/GenBank/EMBL) using the FASTA program (Pearson \& Lipman, 1988) and aligned with CLUSTAL X software version 1.83 (Thompson et al., 1997). Phylogenetic trees were then constructed based on neighbour-joining, minimum evolution and maximum-parsimony methods using MEGA 3.1 (Kumar et al., 2004) and compared with those inferred by using the SEQBOOT, DNADIST, DNAMLK and CONSENSE programs of the PHYLIP package version 3.6 (Felsenstein, 2004) through 100-1000 bootstrap replications. Rooted trees which showed only minor differences in topology and high frequency of bootstrapping were chosen for phylogenetic analysis.

Non-radioactive digoxigenin-labelling DNA hybridization and anti-digoxigenin chemiluminescent detection methods were applied to determine DNA-DNA relatedness of the novel strains to all type strains of the genus Halobacillus. DIG-11-dUTP-labelled ssDNAs were hybridized with reference ssDNAs immobilized on positively charged nylon filter membrane (Brown, 1995) using DIG-High Prime DNA Labelling, Detection Starter kit II and DIG Wash and Block buffer set (Roche Molecular Biochemicals) under the manufacturer's instructions. The chemiluminescent density of hybrids was detected using the VersaDoc Imaging System model 5000 and analysed with Quantity One software version 4.4 (Bio-Rad). Experiments were repeated three times. The $\mathrm{G}+\mathrm{C}$ content of the strains was determined by capillary zone electrophoresis (CZE) (Fraga et al., 2002; Hua \& Naganuma, 2007). Highly purified genomic DNAs were enzymically hydrolysed into nucleosides (Tamaoka \& Komagata, 1984; Mesbah et al., 1989) and nucleosides were then eluted in an alkaline phosphate buffer system, separated and detected quantitatively by a CAPI-3300 multichannel CZE (Otsuka Electronics). Cellular fatty acids were extracted and analysed using conventional GC-MS methods (Sasser, 2001). Quinones were extracted from cells according to Nishijima et al. (1997) and analysed by HPLC. Bacterial cell walls were hydrolysed and peptidoglycans were extracted and purified using highperformance TLC. The amino acid composition of hydrolysed peptidoglycans was detected using HPLC (Komagata \& Suzuki, 1987). 
The 16S rRNA gene sequences of strains IS- $\mathrm{Hb} 4^{\mathrm{T}}$ and IS$\mathrm{Hb} 7^{\mathrm{T}}$ showed high similarity to those of type strains of genus Halobacillus, H. halophilus NCIMB $9251^{\mathrm{T}}$ (97.3 and $96.4 \%$, respectively), $H$. trueperi DSM $10404^{\mathrm{T}}$ (98.9 and $\left.97.9 \%\right), H$. litoralis SL-4 ${ }^{\mathrm{T}}$ (98.8 and 97.8\%), H. karajensis DSM $14948^{\mathrm{T}}$ (99.2 and $98.1 \%$ ), H. salinus HSL-3 ${ }^{\mathrm{T}}$ (97.8 and $\left.97.0 \%\right), H$. locisalis SL-4 ${ }^{\mathrm{T}}$ (98.3 and 97.6\%), H. yeomjeoni MSS $-402^{\mathrm{T}}$ (98.2 and $97.7 \%), H$. aidingensis $\mathrm{AD}-6^{\mathrm{T}}$ (98.0 and $97.2 \%$ ) and $H$. dabanensis $\mathrm{D}-8^{\mathrm{T}}$ (99.4 and $98.5 \%$ ) (see Supplementary Table S1 in IJSEM Online), confirming their close relationship at the species level in this genus. Phylogenetic relationships of strains IS- $\mathrm{Hb} 4^{\mathrm{T}}$ and IS- $\mathrm{Hb} 7^{\mathrm{T}}$ and other type strains as well as other species of bacilli are shown in Fig. 1. The novel strains shared low levels of DNA-DNA relatedness with $H$. halophilus DSM $2266^{\mathrm{T}}$ (12.2 and $30.7 \%$ relatedness, respectively, with IS- $\mathrm{Hb} 4^{\mathrm{T}}$ and IS- $\left.\mathrm{Hb} 7^{\mathrm{T}}\right), H$. trueperi DSM $10404^{\mathrm{T}}$ (33.0 and 20.1\%), H. litoralis DSM $10405^{\mathrm{T}}(24.6$ and $14.7 \%)$, H. karajensis DSM $14948^{\mathrm{T}}(10.4$ and $27.4 \%)$, H. salinus JCM $11546^{\mathrm{T}}$ (25.4 and $\left.18.6 \%\right), H$. locisalis (8.5 and $23.5 \%)$, H. yeomjeoni DSM $17110^{\mathrm{T}}(1.0$ and $1.4 \%), H$. aidingensis DSM $18198^{\mathrm{T}}$ (17.1 and $\left.23.4 \%\right)$ and $H$. dabanensis DSM $18199^{\mathrm{T}}$ (6.0 and $5.3 \%$ ) (Supplementary Table S1). DNA-DNA relatedness between the two strains was $49.5 \%$. The results above indicated sufficient genotypic evidence for their assignment to separate novel species (Wayne et al., 1987).

Biochemical data showed that the cell walls of the new isolates contains the L-Orn-D-Asp-based type of peptidoglycan that is also found in other Halobacillus species (Spring et al., 1996). MK-7 was detected as the main menaquinone of strains IS- $\mathrm{Hb} 4^{\mathrm{T}}$ and IS- $-\mathrm{Hb} 7^{\mathrm{T}}$. Unlike other Halobacillus species, which often produce the predominant fatty acids anteiso- $\mathrm{C}_{15: 0}$, anteiso- $\mathrm{C}_{17: 0}$, iso- $\mathrm{C}_{14: 0}$, iso- $\mathrm{C}_{15: 0}$ and iso- $\mathrm{C}_{16: 0}$, the deep-sea isolates IS- $\mathrm{Hb} 4^{\mathrm{T}}$ and IS- $\mathrm{Hb} 7^{\mathrm{T}}$ showed high percentages of $\mathrm{C}_{16: 0}(28.22$ and $20.28 \%$, respectively), $\mathrm{C}_{16: 1} \omega 7 c$ alcohol (12.25 and $\left.8.47 \%\right)$, $\mathrm{C}_{18: 1} \omega 7 c$ (30.99 and $\left.25.98 \%\right)$ and $\mathrm{C}_{19: 0}$ cyc (18.99 and $14.54 \%)$ in their fatty acid profiles. Furthermore, some acids, such as $\mathrm{C}_{12: 0} \omega 7$ and $\mathrm{C}_{17: 0} \mathrm{cyc}$, were found in these isolates for the first time within the halobacilli (Table 1). The DNA G $+\mathrm{C}$ contents of strains IS- $-\mathrm{Hb}^{\mathrm{T}}$ and IS-Hb7 ${ }^{\mathrm{T}}$ were 43.3 and $42.1 \mathrm{~mol} \%$, respectively (Table 2 ).

The deep-sea isolates shared common morphological and physiological characteristics with Halobacillus type strains as noted in the species descriptions and Table 2. Under increased hydrostatic pressure, growth was observed in all cases from 0.1 to $30.0 \mathrm{MPa}$. Weak growth of strain IS- $\mathrm{Hb} 4^{\mathrm{T}}$ and IS-Hb7 ${ }^{\mathrm{T}}$ (small colonies of about $0.5 \mathrm{~mm}$ in diameter after $48 \mathrm{~h}$, with slow growth and little increase in $\mathrm{OD}_{600}$ ) was observed under anaerobic conditions and strain IS$\mathrm{Hb} 4^{\mathrm{T}}$ (but not strain IS- $-\mathrm{Hb}^{\mathrm{T}}$ ) reduced nitrate to nitrite; these differences from other species of the genus Halobacillus show a tendency of adaptation of these strains to the deep-sea environment. If so, they are the first members of the genus Halobacillus to share anaerobic activity with Bacillus species (Marino et al., 2000, 2001; Ye et al., 2000).

\section{Description of Halobacillus profundi sp. nov.}

Halobacillus profundi (pro.fun'di. L. gen. n. profundi of the depths of the sea, of the deep-sea).

Rod-shaped, Gram-positive, non-motile cells, $0.5-1.0$ by $1.0-2.9 \mu \mathrm{m}$, occur singly or in pairs or short chains (Fig. 2a). Endospores are spherical or ellipsoidal and are located in a central position. Colonies are circular, convex with entire margins, pale yellow in colour and $1.5-2.5 \mathrm{~mm}$ in diameter after 3 days. Temperature range for growth is $9-47^{\circ} \mathrm{C}$ (optimum $25^{\circ} \mathrm{C}$ ). Growth occurs in medium

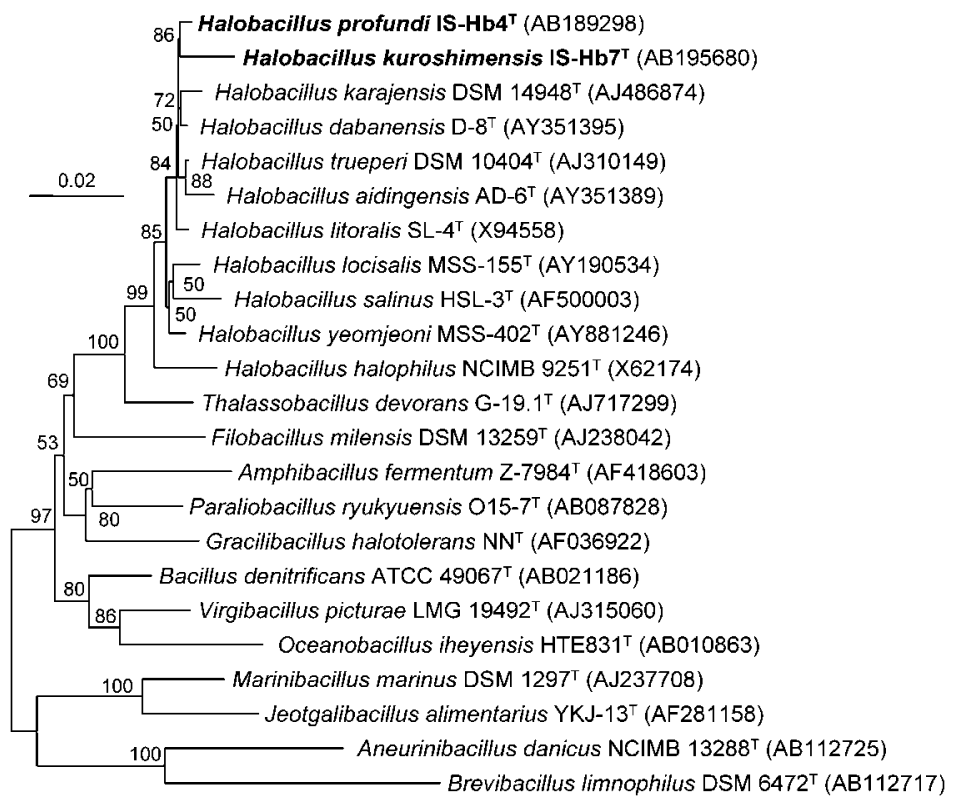

Fig. 1. Neighbour-joining phylogenetic tree showing relationships of the deep-sea strains IS-Hb4 ${ }^{\top}$ and IS-Hb7 ${ }^{\top}$ to other type strains in genus Halobacillus and other related bacteria based on 16S rRNA gene sequences. Values of bootstrap greater than or equal to $50 \%$ (from 1000 replications) are shown at nodes. Bar, 0.02 substitutions per site. 
Table 1. Cellular fatty acid composition of strains IS-Hb4 $4^{\top}$ and $\mathrm{IS}-\mathrm{Hb} 7^{\top}$ and type strains of the genus Halobacillus

Strains: 1, strain IS-Hb4 $4^{\mathrm{T}} ; 2$, strain IS-Hb7 ${ }^{\mathrm{T}} ; 3$, H. halophilus $3^{\mathrm{T}}$ (data from Claus et al., 1983); 4, H. trueperi SL-5 ${ }^{\mathrm{T}}$ (Spring et al., 1996); 5, H. litoralis SL-4 ${ }^{\mathrm{T}}$ (Spring et al., 1996); 6, H. karajensis MA-2 ${ }^{\mathrm{T}}$ (Amoozegar et al., 2003b); 7, H. salinus HSL-3 ${ }^{\mathrm{T}}$ (Yoon et al., 2003); 8, H. locisalis MSS- $155^{\mathrm{T}}$ (Yoon et al., 2004); 9, H. yeomjeoni MSS-402 ${ }^{\mathrm{T}}$ (Yoon et al., 2005); 10, H. aidingensis AD-6 ${ }^{\mathrm{T}}$ (Liu et al., 2005); 11 , H. dabanensis $\mathrm{D}-8^{\mathrm{T}}$ (Liu et al., 2005). Strains IS- $\mathrm{Hb} 4^{\mathrm{T}}$ and $\mathrm{IS}-\mathrm{Hb} 7^{\mathrm{T}}$ were cultured at their optimal temperature $\left(25^{\circ} \mathrm{C}\right)$ and $\mathrm{NaCl}$ concentration (10 and $6 \% \mathrm{NaCl}$, respectively). Values are percentages of fatty acids. ND, Not detected/not reported.

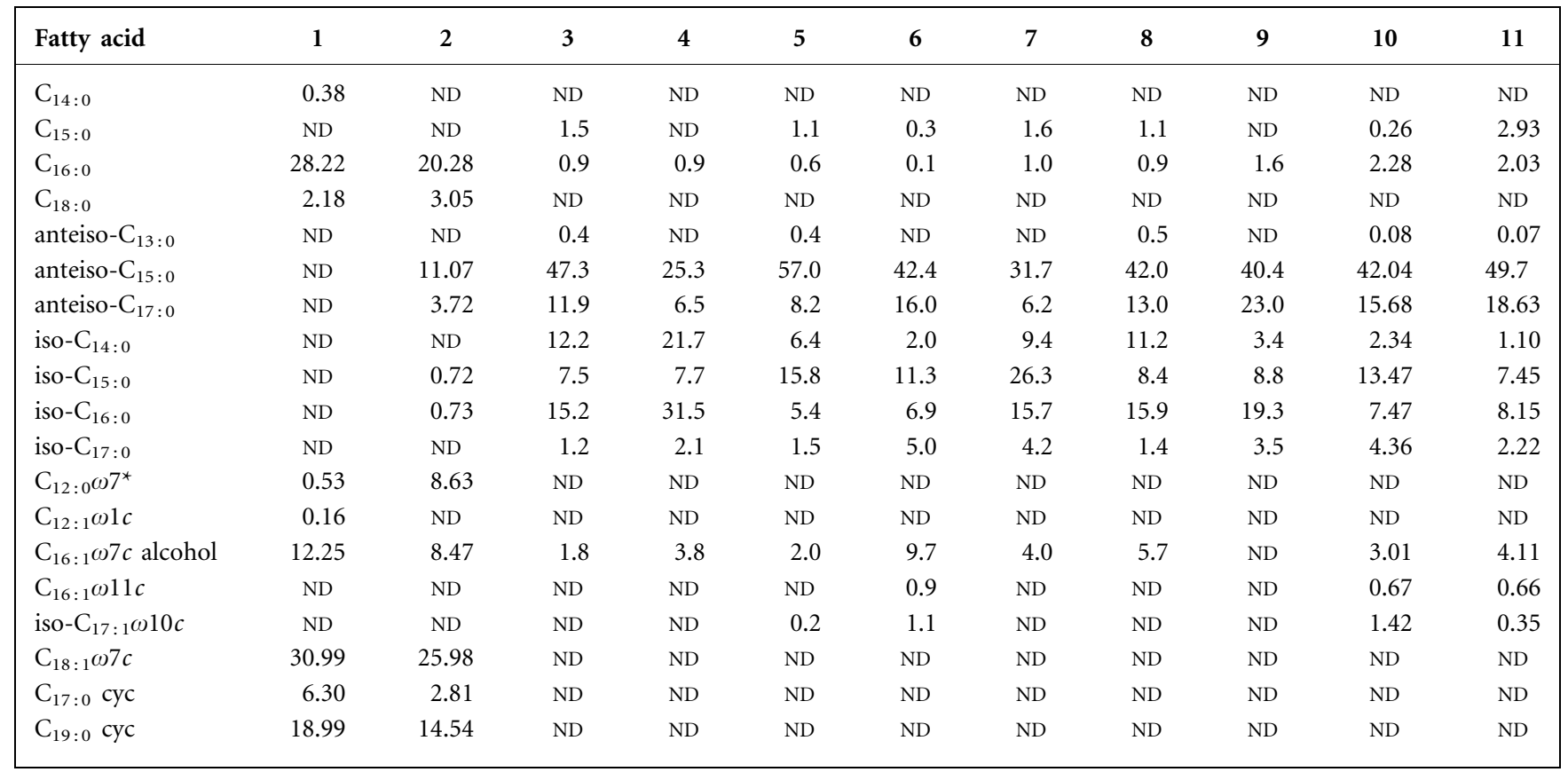

${ }^{*}$ Unknown fatty acid.

containing $0.5-30 \%(\mathrm{w} / \mathrm{v}) \mathrm{NaCl}$ (optimum $10 \%$ ). The $\mathrm{pH}$ range for growth is 5.5-10.0 (optimum $\mathrm{pH}$ 7.5-8.0). Weak growth is observed under anaerobic conditions. Nitrate is variably reduced to nitrite. Catalase- and oxidase-positive. Acid-fastness, phenylalanine deaminase and urease tests are negative. Tweens 20, 40 and 80, starch, casein and aesculin are hydrolysed. Gelatin, dextrin, $\alpha$-cyclodextrin and glycogen are not hydrolysed. Acid is produced from D-fructose, maltose, D-glucose, D-xylose, D-mannitol, maltose, mannose, rhamnose, sucrose, trehalose, raffinose, mannitol, sorbitol and $\mathrm{N}$-acetylglucosamine. Acid is not produced from D-tagatose, cellobiose, D-galactose, melibiose, cellobiose or inositol. The following substrates are utilized as single sources of carbon: $N$-acetyl-D-glucosamine, i-erythritol, $\alpha$-D-lactose, D-mannitol, pyruvic acid methyl ester, $\alpha$-cyclodextrin, Tweens 40 and 80, $\alpha$-ketoglutaric acid, $\alpha$-ketobutyric acid, $\alpha$-ketovaleric acid, D-saccharic acid, sebacic acid, L-glutamic acid, glycyl L-aspartic acid and D-serine (Supplementary Table S2). The cell wall contains peptidoglycan based on L-Orn-D-Asp. The major menaquinone is $\mathrm{MK}-7$. Major fatty acids are $\mathrm{C}_{16: 0}, \mathrm{C}_{16: 1} \omega 7 c$ alcohol, $\mathrm{C}_{18: 1} \omega 7 c$ and $\mathrm{C}_{19: 0}$ cyc. The DNA $\mathrm{G}+\mathrm{C}$ content of the type strain is $43.3 \mathrm{~mol} \%$ (determined by CZE).

The type strain, IS-Hb4 ${ }^{\mathrm{T}}$ ( = JCM $14154^{\mathrm{T}}=\mathrm{DSM} 18394^{\mathrm{T}}$ ), was isolated from a carbonate rock collected from a 642 m-deep methane cold seep in Kuroshima Knoll, southwestern Japan.

\section{Description of Halobacillus kuroshimensis sp. nov.}

Halobacillus kuroshimensis (ku.ro.shi.men'sis. N.L. masc. adj. kuroshimensis from Kuroshima, Japan, where the type strain was isolated).

Rod-shaped, Gram-positive, non-motile cells, $0.5-1.0$ by 1.6-3.3 $\mu \mathrm{m}$, occur singly or in pairs or short chains (Fig. 2b). Endospores are spherical or ellipsoidal and are located in a terminal position. Colonies are circular, convex with entire margins, yellow-orange in colour and 1.5$2.5 \mathrm{~mm}$ in diameter after 3 days. Temperature range for growth is $9-48{ }^{\circ} \mathrm{C}$ (optimum $25^{\circ} \mathrm{C}$ ). Growth occurs in medium containing 0.5-25\% (w/v) NaCl (optimum 6\%). $\mathrm{pH}$ range for growth is 5.5-10.0 (optimum $\mathrm{pH} 7.5-8.0$ ). Growth occurs weakly under anaerobic conditions. Nitrate is not reduced to nitrite. Catalase- and oxidase-positive. Acid-fastness, phenylalanine deaminase and urease tests are negative. Tweens 20, 40 and 80 , starch, gelatin, casein and aesculin are hydrolysed. Dextrin, $\alpha$-cyclodextrin and glycogen are not hydrolysed. Acid is produced from D-fructose, D-glucose, maltose, mannose, inositol, glycerol, 
Table 2. Phenotypic features of strains $\mathrm{IS}-\mathrm{Hb} 4^{\top}$ and $\mathrm{IS}-\mathrm{Hb} 7^{\top}$ in comparison with other Halobacillus species

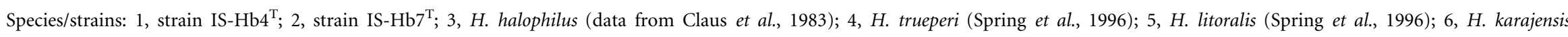

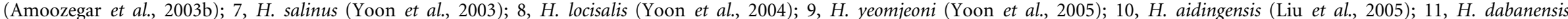
(Liu et al., 2005). All strains are positive in Gram staining, catalase and oxidase and negative for urease activity. +, Positive; - , negative; W, weak; V, variable; ND, no data available.

\begin{tabular}{|c|c|c|c|c|c|c|c|c|c|c|c|}
\hline Characteristic & 1 & 2 & 3 & 4 & 5 & 6 & 7 & 8 & 9 & 10 & 11 \\
\hline Cell morphology & Rods & Rods & Coccoid & Rods & Rods & Rods & Rods & Rods & Rods & Clubs & Rods \\
\hline Mobility & - & - & + & + & + & - & + & + & + & + & + \\
\hline \multicolumn{12}{|l|}{ Spore morphology* } \\
\hline Shape & $\mathrm{E} / \mathrm{s}$ & $\mathrm{E} / \mathrm{s}$ & S & $\mathrm{E} / \mathrm{S}$ & $\mathrm{E}$ & $\mathrm{E} / \mathrm{s}$ & $\mathrm{E} / \mathrm{s}$ & E & E & E & $\mathrm{E}$ \\
\hline Position & $\mathrm{C}$ & $\mathrm{T}$ & $\mathrm{C} / \mathrm{L}$ & $\mathrm{C} / \mathrm{sT}$ & $\mathrm{C} / \mathrm{sT}$ & $\mathrm{C} / \mathrm{sT}$ & $\mathrm{C} / \mathrm{sT}$ & $\mathrm{C} / \mathrm{sT}$ & $\mathrm{C} / \mathrm{ST}$ & $\mathrm{C} / \mathrm{sT}$ & $\mathrm{C} / \mathrm{sT}$ \\
\hline \multicolumn{12}{|l|}{ Growth conditions } \\
\hline Temperature $\left({ }^{\circ} \mathrm{C}\right)$ & $9-47$ & $9-48$ & $15-40$ & $10-44$ & $10-43$ & $10-49$ & $10-45$ & $10-42$ & $15-48$ & $15-40$ & $15-50$ \\
\hline $\mathrm{pH}$ & $5.5-10.0$ & $5.5-10.0$ & $7.0-9.0$ & $6.0-9.5$ & $6.0-9.5$ & $6.0-9.6$ & ND & $5.0-9.5$ & $6.0-\mathrm{ND}$ & $6.0-10.0$ & $5.0-11.0$ \\
\hline $\mathrm{NaCl}$ concentration $(\%, \mathrm{w} / \mathrm{v})$ & $0.5-30.0$ & $0.5-25.0$ & $2.0-20.0$ & $0.5-30.0$ & $0.5-25.0$ & $1.0-24.0$ & $0.0-23.0$ & $>0-23.0$ & $0.5-21.0$ & $0.5-20.0$ & $0.5-25.0$ \\
\hline Nitrate reduction & V & - & - & - & - & - & - & - & - & - & - \\
\hline \multicolumn{12}{|l|}{ Hydrolysis of: } \\
\hline Gelatin & - & + & + & + & + & + & + & - & + & + & - \\
\hline Aesculin & + & + & - & - & - & + & + & + & - & - & - \\
\hline Casein & + & + & + & - & - & + & + & - & + & + & + \\
\hline Starch & + & + & - & - & - & + & - & + & - & + & + \\
\hline Tween 80 & + & + & + & - & - & - & + & + & + & - & - \\
\hline \multicolumn{12}{|l|}{ Acid production from: } \\
\hline D-Galactose & - & - & - & + & - & - & $\mathrm{w}$ & - & - & - & - \\
\hline Sucrose & + & $\mathrm{w}$ & - & + & + & - & + & + & + & + & + \\
\hline D-Xylose & + & - & - & - & + & - & - & - & - & - & + \\
\hline D-Mannitol & + & - & - & - & + & + & + & - & + & + & + \\
\hline D-Trehalose & + & - & - & + & + & ND & + & + & + & + & + \\
\hline Maltose & + & + & - & + & + & + & + & - & + & + & + \\
\hline DNA G $+\mathrm{C}$ content $(\mathrm{mol} \%)$ & 43.3 & 42.1 & $40.1-40.9$ & 43.0 & 42.0 & 41.3 & 45.0 & 44.0 & 42.9 & 42.2 & 41.4 \\
\hline
\end{tabular}

${ }^{\star}$ Spore shape: E, ellipsoidal; S, spherical. Spore position: C, central; L, lateral; ST, subterminal; T, terminal. 

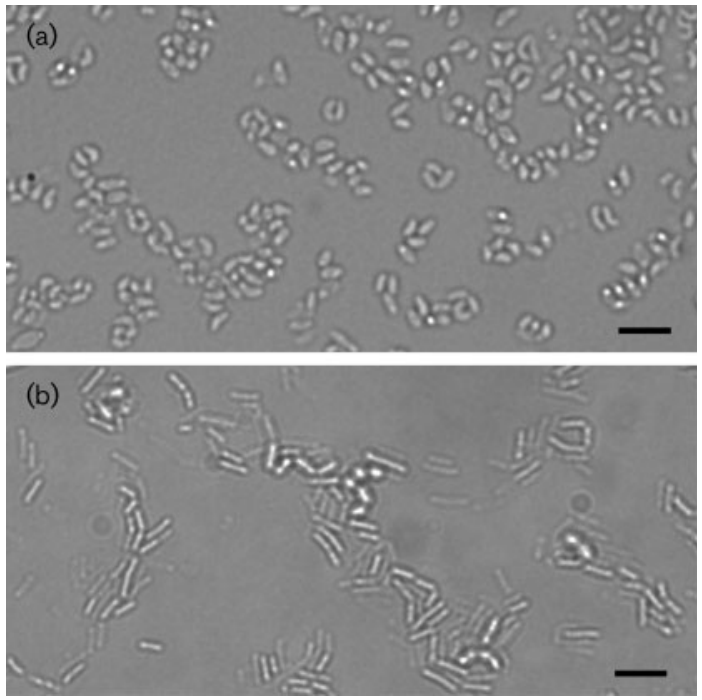

Fig. 2. Phase-contrast micrographs of cells of strains $\mathrm{IS}-\mathrm{Hb} 4^{\top}$ (a) and IS-Hb7 ${ }^{\top}$ (b). Bars, $5 \mu \mathrm{m}$.

$\mathrm{N}$-acetylglucosamine, sucrose and cellobiose. Acid is not produced from D-tagatose, D-galactose, salicin, D-xylose, Dmannitol, D-trehalose or melibiose. D-Xylose, $\alpha$-D-glucose, myo-inositol, maltose, D-mannose and Tweens 40 and 80 are utilized as single carbon sources (Supplementary Table S2). The cell wall contains peptidoglycan based on L-Orn-D-Asp. The major menaquinone is MK-7. Fatty acids $\mathrm{C}_{16: 1} \omega 7 c$ alcohol, $\mathrm{C}_{18: 1} \omega 7 c$ and $\mathrm{C}_{19: 0} \mathrm{cyc}$ are abundant. The DNA $\mathrm{G}+\mathrm{C}$ content of the type strain is $42.1 \mathrm{~mol} \%$ (determined by CZE).

The type strain, IS-Hb7 ${ }^{\mathrm{T}}\left(=\mathrm{JCM} 14155^{\mathrm{T}}=\mathrm{DSM} 18393^{\mathrm{T}}\right)$, was isolated from the same sample as strain IS- $\mathrm{Hb} 4^{\mathrm{T}}$.

\section{Acknowledgements}

We thank the operation team of the ROV Dolphin $3 \mathrm{~K}$ and the crew of the RV Natsushima, JAMSTEC, for their help in the collection of carbonate specimens. This work was supported by the Special Coordination Fund 'Archaean Park Project: International Research Project on Interaction between Subvent Biosphere and Geo-environments' of the Japan Science and Technology Agency and Grants-in-Aid for Scientific Research (11204205 and 14340268) from the Japan Society for the Promotion of Science.

\section{References}

Amoozegar, M. A., Malekzadeh, F. \& Malik, K. A. (2003a). Production of amylase by newly isolated moderate halophile, Halobacillus sp. strain MA-2. J Microbiol Methods 52, 353-359.

Amoozegar, M. A., Malekzadeh, F., Malik, K. A., Schumann, P. \& Spröer, C. (2003b). Halobacillus karajensis sp. nov., a novel moderate halophile. Int J Syst Evol Microbiol 53, 1059-1063.

Brown, T. (1995). Dot and slot blotting of DNA. In Short Protocols in Molecular Biology, 3rd edn, pp. 2.33-2.35. Edited by F. M. Ausubel, R. Brent, R. E. Kingston, D. D. Moore, J. G. Seidman, J. A. Smith \& K. Struhl. Chichester: Wiley.
Burja, A. M., Webster, N. S., Murphy, P. T. \& Hill, R. T. (1999). Microbial symbionts of Great Barrier Reef sponges. Mem Queensl Mus 44, 63-75.

Claus, D., Fahmy, F., Rolf, H. \& Tosunoglu, N. (1983). Sporosarcina halophila sp. nov., an obligate, slightly halophilic bacterium from salt marsh soils. Syst Appl Microbiol 4, 496-506.

DeLong, E. F. (1992). Archaea in coastal marine environments. Proc Natl Acad Sci U S A 89, 5685-5689.

Doetsch, R. N. (1981). Determinative methods of light microscopy. In Manual of Methods for General Bacteriology, pp. 21-33. Edited by P. Gerhardt, R. G. E. Murray, R. N. Costilow, E. W. Nester, W. A. Wood, N. R. Krieg \& G. B. Phillips. Washington, DC: American Society for Microbiology.

Felsenstein, J. (2004). PHYLIP - Phylogeny Inference Package, version 3.6. Distributed by the author. Department of Genome Sciences, University of Washington, Seattle, USA.

Fraga, M. F., Uriol, E., Diego, L. B., Berdasco, M., Esteller, M., Canal, M. J. \& Rodriguez, R. (2002). High-performance capillary electrophoretic method for the quantification of 5-methyl 2'-deoxycytidine in genomic DNA: application to plant, animal and human cancer tissues. Electrophoresis 23, 1677-1681.

Fujikura, K., Aoki, M., Fujiwara, Y., Ichibayashi, S., Imamura, M., Ishibashi, J., Iwase, R., Kato, K., Kosaka, A. \& other authors (2003). Report of investigation of vent and methane seep ecosystems by the crewed submersible 'Shinkai 2000' and the ROV 'Dolphin 3K' on the Hatoma and the Kuroshima Knolls, the Nansei-shoto area. JAMSTEC J Deep Sea Res 22, 21-30 (in Japanese with English abstract).

Garland, J. L. (1996). Analytical approaches to the characterization of samples of microbial community using patterns of potential C source utilization. Soil Biol Biochem 28, 213-221.

Garland, J. L. (1999). Potential and limitation of BIOLOG for microbial community analysis. In Microbial Biosystems: New Frontiers. Proceedings of the 8th International Symposium on Microbial Ecology. Edited by C. R. Bell, M. Brylinsky \& P. Johnson-Green. Halifax, Nova Scotia: Atlantic Canada Society for Microbial Ecology.

Garland, J. L. \& Mills, A. L. (1991). Classification and characterization of heterotrophic microbial communities on the basis of patterns of community-level sole-carbon-source utilization. Appl Environ Microbiol 57, 2351-2359.

Hua, N.-P. \& Naganuma, T. (2007). Application of CE for determination of DNA base composition. Electrophoresis 28, 366-372.

Inagaki, F., Tsunogai, U., Suzuki, M., Kosaka, A., Machiyama, H., Takai, K., Nunoura, T., Nealson, K. H. \& Hirokoshi, K. (2004). Characterization of $\mathrm{C} 1$-metabolizing prokaryotic communities in methane seep habitats at the Kuroshima Knoll, southern Ryukyu Arc, by analyzing pmoA, mmoX, mxaF, mcrA, and $16 \mathrm{~S}$ rRNA genes. Appl Environ Microbiol 70, 7445-7455.

Komagata, K. \& Suzuki, K. (1987). Lipid and cell wall analysis in bacterial systematics. Methods Microbiol 19, 161-207.

Kumar, S., Tamura, K. \& Nei, M. (2004). MEGA3: integrated software for molecular evolutionary genetics analysis and sequence alignment. Brief Bioinform 5, 150-163.

Liu, W. Y., Zeng, J., Wang, L., Dou, Y. T. \& Yang, S. S. (2005). Halobacillus dabanensis sp. nov. and Halobacillus aidingensis sp. nov., isolated from salt lakes in Xinjiang, China. Int J Syst Evol Microbiol 55, 1991-1996.

Marino, M., Hoffmann, T., Schmid, R., Mobitz, H. \& Jahn, D. (2000). Changes in protein synthesis during the adaptation of Bacillus subtilis to anaerobic conditions. Microbiology 146, 97-105.

Marino, M., Ramos, H. C., Hoffmann, T., Glaser, P. \& Jahn, D. (2001). Modulation of anaerobic energy metabolism of Bacillus subtilis by arfM (ywiD). J Bacteriol 183, 6815-6821. 
Mesbah, M., Premachandran, U. \& Whitman, W. B. (1989). Precise measurement of the $\mathrm{G}+\mathrm{C}$ content of deoxyribonucleic acid by high-performance liquid chromatography. Int J Syst Bacteriol 39, 159-167.

Nishijima, M., Araki-Sakai, M. \& Sano, H. (1997). Identification of isoprenoid quinones by frit-FAB liquid chromatography-mass spectrometry for the chemotaxonomy of microorganisms. J Microbiol Methods 28, 113-122.

Okamoto, T. (2004). Phylogenetic analyses of the euryhalophilic microorganisms isolated from extreme environments. Doctoral thesis, Graduate School of Biosphere Sciences, Hiroshima University, Japan.

Okamoto, T. \& Naganuma, T. (2003). Distribution of euryhaline halophilic microorganisms at non-hypersaline environments. In Abstracts of the Earth and Planetary Science Joint Meeting, 26-29 May 2003, Chiba, Japan. Abstract B001-p005.

Okamoto, T., Fujioka, K. \& Naganuma, T. (2001). Phylogenetic similarity of aerobic gram-negative halophilic bacteria from a deepsea hydrothermal mound and Antarctic habitats. Polar Biosci 14, 1-9.

Pearson, W. R. \& Lipman, D. J. (1988). Improved tools for biological sequence comparison. Proc Natl Acad Sci U S A 85, 2444-2448.

Pinar, G., Ramos, C., Rolleke, S., Schabereiter-Gurtner, C., Vybiral, D., Lubitz, W. \& Denner, E. B. (2001). Detection of indigenous Halobacillus populations in damaged ancient wall painting and building materials: molecular monitoring and cultivation. Appl Environ Microbiol 67, 4891-4895.

Rivadeneyra, M. A., Párraga, J., Delgado, R., Ramos-Cormenzana, A. \& Delgado, G. (2004). Biomineralization of carbonates by Halobacillus trueperi in solid and liquid media with different salinities. FEMS Microbiol Ecol 48, 39-46.

Sasser, M. (2001). Identification of bacteria by gas chromatography of cellular fatty acids, Technical Note 101. Newark, DE: MIDI Inc.

Smibert, R. M. \& Krieg, N. R. (1981). General characterization. In Manual of Methods for General Bacteriology, pp. 409-443. Edited by P. Gerhardt, R. G. E. Murray, R. N. Costilow, E. W. Nester, W. A. Wood, N. R. Krieg \& G. B. Phillips. Washington, DC: American Society for Microbiology.
Spring, S., Ludwig, W., Marquez, M. C., Ventosa, A. \& Schleifer, K. H. (1996). Halobacillus gen. nov., with descriptions of Halobacillus litoralis sp. nov. and Halobacillus trueperi sp. nov., and transfer of Sporosarcina halophila to Halobacillus halophilus comb. nov. Int J Syst Bacteriol 46, 492-496.

Tamaoka, J. \& Komagata, K. (1984). Determination of DNA base composition by reversed-phase high-performance liquid chromatography. FEMS Microbiol Lett 25, 125-128.

Thompson, J. D., Gibson, T. J., Plewniak, F., Jeanmougin, F. \& Higgins, D. G. (1997). The CLUSTAL_W windows interface: flexible strategies for multiple sequence alignment aided by quality analysis tools. Nucleic Acids Res 25, 4876-4882.

Wayne, L. G., Brenner, D. J., Colwell, R. R., Grimont, P. A. D., Kandler, O., Krichevsky, M. I., Moore, L. H., Moore, W. E. C., Murray, R. G. E. \& other authors (1987). Report of the ad hoc committee on reconciliation of approaches to bacterial systematics. Int $J$ Syst Bacteriol 37, 463-464.

Wilson, K. (1995). Preparation of genomic DNA from bacteria. In Short Protocols in Molecular Biology, 3rd edn, pp. 2.11-2.13. Edited by F. M. Ausubel, R. Brent, R. E. Kingston, D. D. Moore, J. G. Seidman, J. A. Smith \& K. Struhl. Chichester: Wiley.

Yang, L., Tan, R.-X., Wang, Q., Huang, W.-Y. \& Yin, Y.-X. (2002). Antifungal cyclopeptides from Halobacillus litoralis YS3106 of marine origin. Tetrahedron Lett 43, 6545-6548.

Ye, R. W., Tao, W., Bedzyk, L., Young, T., Chen, M. \& Li, L. (2000). Global gene expression profiles of Bacillus subtilis grown under anaerobic conditions. J Bacteriol 182, 4458-4465.

Yoon, J. H., Kang, K. H. \& Park, Y. H. (2003). Halobacillus salinus sp. nov., isolated from a salt lake on the coast of the East Sea in Korea. Int J Syst Evol Microbiol 53, 687-693.

Yoon, J. H., Kang, K. H., Oh, T. K. \& Park, Y. H. (2004). Halobacillus locisalis sp. nov., a halophilic bacterium isolated from a marine solar saltern of the Yellow Sea in Korea. Extremophiles 8, 23-28.

Yoon, J.-H., Kang, S.-J., Lee, C.-H., Oh, H. W. \& Oh, T.-K. (2005). Halobacillus yeomjeoni sp. nov., isolated from a marine solar saltern in Korea. Int J Syst Evol Microbiol 55, 2413-2417. 